\title{
Dry matter production and allocation of two Khaya species in response to water availability
}

\author{
Richard GYIMAH ${ }^{1, *}$ and Toshio NAKAO ${ }^{2}$ \\ The United Graduate School of Agricultural Sciences, Kagoshima University, \% Faculty of Agriculture, University of Miyazaki, 889-2192 \\ Miyazaki-shi, Japan. \\ Department of Biological Production and Environmental Sciences, Faculty of Agriculture, University of Miyazaki, 889-2192 Miyazaki-shi, \\ Japan. \\ * Corresponding author: E-mail: rich_gyimah@yahoo.com Tel/ Fax: +81-985-58-7177
}

\begin{abstract}
Effects of soil water availability on seedling height, dry matter production and allocation were investigated for Khaya anthotheca (a typical species at drier sites in a moist deciduous forest) and Khaya ivorensis (a typical species at wetter sites in a moist deciduous forest). Twomonth-old seedlings of the two species were subjected to three soil watering treatments, which were termed wet, moderate and dry treatment, in a glass house for 14 weeks. Seedling height growth was significantly influenced by soil water availability and the pattern of height response was speciesspecific. $K$. anthotheca had significantly better growth in the moderate watering treatment than in the wet and dry treatment. As time progressed, plants in the wet treatment of $K$. ivorensis had greatest height growth than in the moderate and dry treatment. Soil water deficit significantly reduced total dry matter production in $K$. ivorensis and altered proportional allocation to leaves and roots as a possible strategy for acclimation. Statistically, water deficit did not affect total dry matter production and allocation in $K$. anthotheca probably due to small sample size used in this study. However, in the moderate and dry treatments, $K$. anthotheca seedlings had greater total plant dry matter than $K$. ivorensis seedlings suggesting that the latter is more tolerant to water deficit and that $K$. anthotheca has considerable potential for plantation forestry in humid tropics of Africa with distinct drought periods.
\end{abstract}

Key words: dry matter production, height growth, Khaya anthotheca, Khaya ivorensis, water stress

\section{INTRODUCTION}

Khaya species is naturally distributed in tropical forest from West to East Africa (Hall \& Swaine, 1981). Khaya anthotheca (welw.) C. DC. and K. ivorensis A. Chev., which are important commercial timber species in Ghana, have been highly exploited over the years. Their prioritized conservation and commercial production are needed (Hawthorne, 2001). The moist semi-deciduous forest type of Ghana shows two floristically distinct subtypes classified by Hall and Swaine (1976) as North-west (NW) and South-east (SE) subtypes. The mean annual rainfall is $1250-1500 \mathrm{~mm}$ and $1500-1750 \mathrm{~mm}$ for the NW and SE subtypes respectively. Hall \& Swaine (1981) observed that $K$. anthotheca is typical in the NW subtype whilst $K$. ivorensis is typical in the SE subtype and moist evergreen forests, which are wetter than moist semi-deciduous forests. However, plants growing in these habitats are seasonally exposed to distinct drought periods (4-5 months) where mean precipitation is less than $100 \mathrm{~mm}$ per month (Hall \& Swaine, 1981). Further, during the course of practical forest management, reforested young stands planted after logging may suffer tissue water deficit because of rapid evaporation from the soil surface and undeveloped juvenile root system (Ito et al., 2000). Thus, it is important to investigate the drought tolerance of the two Khaya species for successful reforestation.

Water regime is one of the important factors in determining plant establishment and productivity (Burton et al., 1998). Soil water deficits cause reductions in total dry matter, leaf production and rate of shoot expansion of woody plants (Osório et al., 1998). Unless soil water deficits are severe and persistent, woody plants acclimate to water deficit through some major drought avoidance mechanisms. This acclimation involves changes in plant structure and function that lead to an enhancement of plant's ability to avoid dehydration, e.g., an increase in 
the ratio of root biomass to foliage area (Li et al., 2000) and altered relative growth of leaves, stems and roots (Kozlowski, 1979; Burton et al., 1998; Osório et al., 1998).

There are limited experimental studies on comparative growth response of $K$. anthotheca and $K$. ivorensis to water stress. Since the two tree species grow at different sites in water availability in actual forests, we expect different responses to water deficits between the two species. The objective of this study was to compare the impacts of water availability on growth, biomass production and allocation patterns for seedlings of the two species.

\section{MATERIALS AND METHODS}

\section{Description of study species}

Khaya anthotheca and Khaya ivorensis belong to the family Meliaceae. They grow up to $50 \mathrm{~m}$ in height as large trees with buttresses. $K$. anthotheca is sometimes briefly deciduous. By contrast, $K$. ivorensis is usually evergreen (Hall \& Swaine, 1981). The two species are monoecious and produce wind-dispersed seeds. In Ghana, seed dispersal usually occurs at the start of wet season or end of dry season for $K$. ivorensis, whereas in the case of $K$. anthotheca, it occurs mostly in dry season (October March)(Hawthorne, 1995). Leaves of both species are paripinnate. In $K$. anthotheca, juvenile leaflets are broadly ovate, but in $K$. ivorensis they are more narrowly oblong, with exceedingly slender drip tips (Hawthorne, 1990).

\section{Plant materials and treatment}

Seeds of K. anthotheca and K. ivorensis were collected from the Brong-Ahafo Regional Forest Services Division's nursery in moist semi-deciduous forest zone of Ghana. Following a standard pre-treatment practice, the seeds were germinated in plastic trays filled with 1:2 volume mixtures of peat and "bora-tsuchi" (light, small porous stones produced from non-weathered substrate of volcanic origin) at a forestry nursery of the University of Miyazaki on April 15, 2003. At two-month old stage, seedlings were transferred into Wagner's pot $(19.5 \mathrm{~cm}$ in length and $17.5 \mathrm{~cm}$ in diameter) and moved to a glass house facility at the University of Miyazaki $\left(32^{\circ} \mathrm{N}\right.$ and $131^{\circ} \mathrm{E}$ ), Japan. Akahoya soil (silt-loam soil) was used as the substrate because of its moderate texture and nutrient contents (Nagatomo \& Tamai, 1993). Over the experiment period, each pot was supplied with a total of $10 \mathrm{~g}$ of slow release 20:10:10 NPK fertilizer to ensure adequate plant nutrition. The potted seedlings were well spaced and grown under a naturally illuminated glass house. Over the experimental period (July 1 to October $15,2003)$ mean daily temperature and humidity recorded in the glass house were $28.5{ }^{\circ} \mathrm{C}$ and $79 \%$ respectively.

Nine seedlings from $K$. anthotheca and $K$. ivorensis were selected for the study on July 1, 2003. At the beginning of treatment, average height \pm (SD) and base diameter $\pm(\mathrm{SD})$ of seedlings were $7.0 \pm(1.3) \mathrm{cm}$ and 2.0 $\pm(0.3) \mathrm{mm}$ respectively for $K$. anthotheca and $7.0 \pm(0.8)$ $\mathrm{cm}$ and $2.0 \pm(0.2) \mathrm{mm}$ respectively for $K$. ivorensis. The experiment comprised two species and three watering treatments with three seedlings per treatment. The pots were randomly arranged into three watering treatments which were termed as wet, moderate and dry treatments. Pots were rotated at least once a week to minimize the effect of environmental differences in the glass house.

In the wet treatment, the soil was maintained at $-0.001 \mathrm{MPa}$ which was equivalent to $100 \%$ or more soil moisture content (SMC) by weight. During rainy periods (6 months), flood-prone banks of water courses in SE subtype and moist evergreen forests where $K$. ivorensis often grows become damp. Thus, the wet treatment was considered to be comparable with site conditions at the SE subtype and moist evergreen forests during rainy season. The NW subtype relatively occupy sites intermediate in moisture (Hall \& Swaine, 1981) and this was equated to moderate watering treatment where soil was maintained at -0.01 to $-0.014 \mathrm{MPa}$ (i.e., $80-76 \%$ $\mathrm{SMC})$. Dry treatment represented a sustained mild water stress approximate to wilting point $(-0.70$ to -1.42$)$ equivalent to $40-35 \% \mathrm{SMC}$. The watering treatment was maintained for 14 weeks. The water potential of the soil was determined using soil moisture content (SMC) versus water potential curve obtained by the centrifuging procedure. The wet treatment was set by maintaining a water level of $3 \mathrm{~cm}$ from the bottom of the pot. Moisture conditions in the moderate and dry treatments were set by watering the pots to field capacity and allowed drying to the desired SMC. To keep soil water close to the target value, pots were weighed every three days and rewatered as needed for weight adjustment. Weight of the seedlings was considered negligible and weight of each pot at the target SMC was calculated as described by Haase and Rose (1993), according to the following equation:

$$
\begin{aligned}
& S M C=(T W-S D W-P) / S D W ; \text { which rearranges } \\
& \text { as } T W=(S M C \times S D W)+S D W+P
\end{aligned}
$$

where $S M C$ is the percentage moisture content on dry weight basis, $T W$ is total weight of dry soil + water + pot weight, $S D W$ is the average weight of dry soil in each pot 
and $P$ is the pot weight.

\section{Growth measurements}

Immediately after transplanting, all seedlings were measured for total height $(\mathrm{H})$. There after, plant height was measured every 21 days until the end of the growing period. Final leaf area (LA) at harvest was determined destructively from scanned leaf images using windows Adobe Photoshop 5.0 software. Biomass was determined at the end of the experiment by harvesting three plants from each treatment. Leaves and stems were separated and soil gently washed from the roots. All plant parts were oven-dried at $70{ }^{\circ} \mathrm{C}$ for 48 hours and thereafter placed in desiccators at the laboratory for 1 hour before dry weight was measured. Total dry matter consisted of leaves, stems, and roots while leaves consisted of leaf blades and petioles. Dry matter allocation among plant components (leaf, stem and root) and root mass per leaf area ratio were calculated from obtained data.

\section{Data analysis}

Height growth measured for both species over time was subjected to repeated measures analysis. Final plant mass production was evaluated using a two-way analysis of variance (ANOVA) including species (2 factors) and treatment (3 factors). Prior to the analysis, final plant mass was transformed to natural logarithms to homogenize variances (Sokal \& Rohlf, 1995). Allocation to plant components and root mass per leaf area ratio within species were subjected to univariate ANOVA; and comparisons between species in those variables at each treatment were made by comparing the mean values due to the small sample size. Comparisons of individual means following ANOVA were done by Fisher's LSD test. All statistical tests were performed using SYSTAT ${ }^{\circledR} 10.2$ (Statistical software Inc., Richmond, CA, USA). Significant differences are reported as $\mathrm{P}<0.05$.

\section{RESULTS}

\section{Height growth}

Height growth $(\mathrm{H})$ over time differed significantly for $K$. anthotheca $(P<0.0001)$ and $K$. ivorensis $(P<0.0001)$. $\mathrm{H}$ showed a highly significant linear increase $(F=212.6, P$ $<0.0001$ ) over time as shown in Figure 1. The pattern of change across time for the watering treatment differed significantly for both species i.e. Time $\times$ Treatment interactions were highly significant for $K$. anthotheca $(P$ $=0.008)$ and $K$. ivorensis $(P=0.001)$. As time progressed, plants in the wet treatment of $K$. ivorensis had greatest height growth than in the moderate and dry treatment. Khaya anthotheca on the other hand, showed the best growth in the moderate watering treatment than in the wet and dry treatment over time. A comparison made between the two species in each watering treatment at final measurement showed that $K$. anthotheca had significantly better growth than $K$. ivorensis in the moderate $(F=14.2, P<0.01)$ and dry treatment $(F=5.1$, $P<0.05)$. On the other hand, $K$. ivorensis grew better than $K$. anthotheca in the wet treatment $(F=5.9, P<0.05)$.

\section{Dry matter production}

The results of the two-way ANOVA indicated that total dry matter production was different between the two species $(F=7.5, P<0.05)$ but not among the treatments $(F=0.8, P>0.05)$. Species $\times$ Treatment interaction was significant $(F=5.0, P<0.05)$. The coefficient of determination $\left(r^{2}\right)$ was 0.61 . Within species, significant differences among the watering treatments in total plant dry mass production was only found in K. ivorensis (Table 1). Relative to the wet treatment, subjecting plants to the moderate and dry treatments reduce mean total plant dry mass by $74 \%$ for $K$. ivorensis. No significant difference among the watering treatment in total plant dry mass was found in $K$. anthotheca, though the mean total dry mass was largest in the moderate treatment. A probable cause may due to small sample size used in this study. However, a comparison made between the two species in each watering treatment revealed that $K$. anthotheca had greater total dry mass production than $K$. ivorensis in the moderate and dry treatments (Table 1). No significant difference between the two species in total plant dry mass production was found in the wet treatment, though the mean total dry mass was larger in K.ivorensis.

\section{Dry matter allocation}

Within each species, there was a preferential and proportionate dry matter allocation to plant components due to the different watering treatments. There were no significant differences among the watering treatments in $K$. anthotheca in the proportion of assimilate allocated to plant components (Table 1 ). The proportion of assimilate allocated to leaves in $K$. ivorensis decreased significantly in the moderate and dry treatments whereas the proportion allocated to roots increased with increasing water deficits. For both species, the proportion of assimilate allocated to the stem did not show significant difference among the watering treatments. Comparatively, mean dry matter allocation to leaves in wet treatment of $K$. anthotheca (52\%) and K. ivorensis 

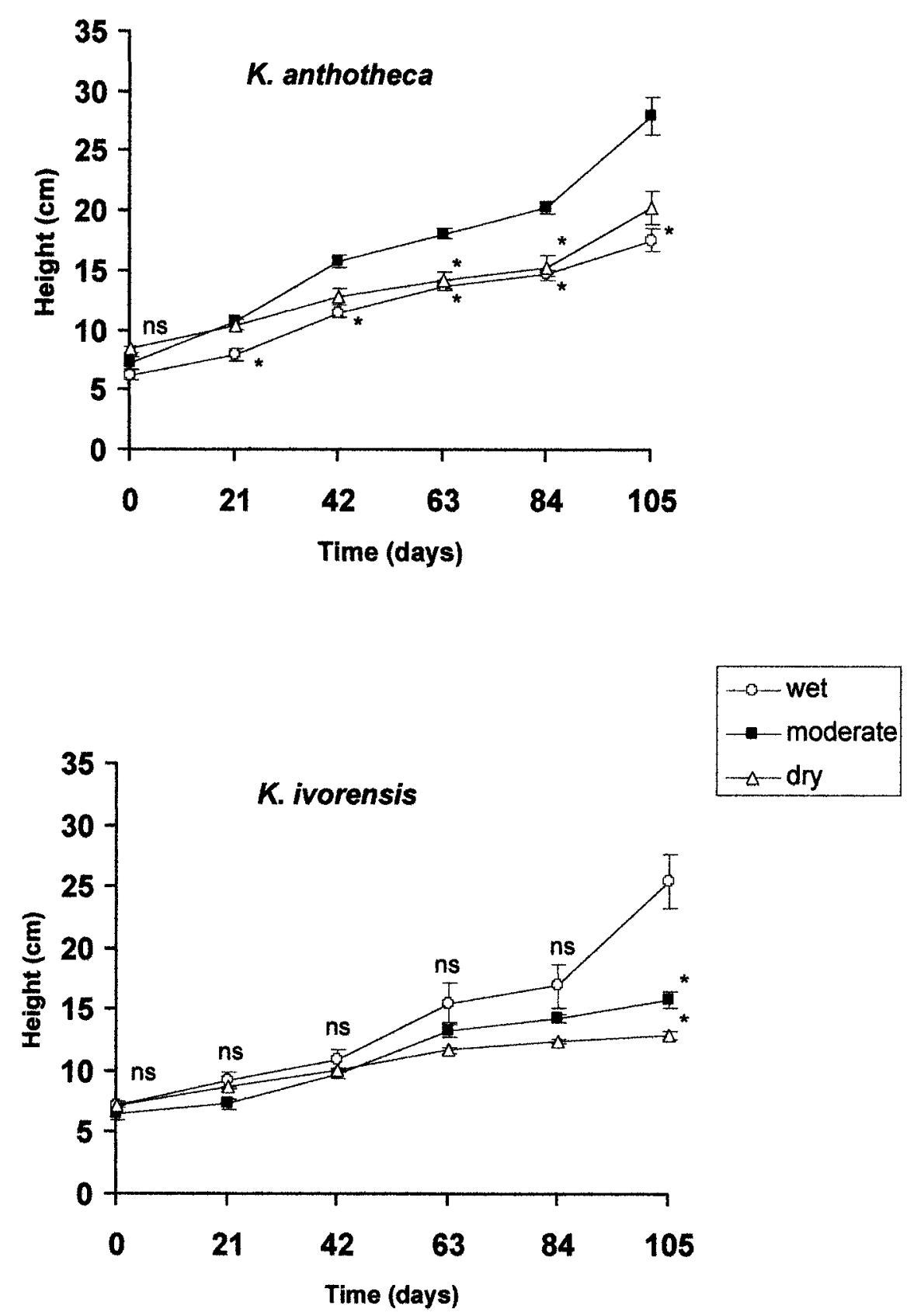

Fig. 1. Height growth of two species subjected to three watering treatments (wet, moderate and dry) over time. Each value is the mean of three plants \pm standard error of mean. Within $K$. anthotheca and $K$. ivorensis seedlings, an asterisk $\left(^{*}\right)$ indicates significant differences from moderate and wet treatment respectively at each measurement day (repeat ANOVA followed by Fisher LSD test, $P<0.05 ;$ ns, $P>$ 0.05).

(49 \%) were similar. However, in the moderate and dry treatments, $K$. anthotheca showed greater percent mean leaf dry matter allocation than $K$. ivorensis (Table 1 ). In contrast, mean root dry matter allocation in the moderate and dry treatments were $29 \%$ and $31 \%$ respectively for $K$. anthotheca and $33 \%$ and $38 \%$ respectively for K. ivorensis. increasing mean values with increasing water deficits. The increase in the ratio was significant in only $K$. ivorensis (Table 2). A comparison in mean values of the ratio between the two species in each treatment showed that $K$. ivorensis had 33 and $50 \%$ proportional increase in the moderate and dry treatments respectively.

Root mass/ foliage area ratio

For both species, root mass: leaf area ratio showed 
Table 1. Effect of watering treatments and species differences on plant dry matter production and the relative proportion of dry matter allocation to leaf, stem and root of $K$. anthotheca and $K$. ivorensis seedlings. Each value is the mean of three plants ( $\pm \mathrm{SE})$. Within each species, means in a column followed by same lower case letters are not significantly different and; different upper case letters in a row represent significant difference between species (Fisher LSD test, $P<0.05$ ).

\begin{tabular}{|c|c|c|c|}
\hline Parameter & Watering regime & K. anthotheca & K. ivorensis \\
\hline \multirow[t]{3}{*}{ Plant dry matter (g) } & Wet & $1.38(0.41)$ a A & $2.41(0.83)$ a A \\
\hline & Moderate & $3.03(1.16)$ a A & $0.62(0.14)$ a B \\
\hline & Dry & $2.40(0.85)$ a $\mathrm{A}$ & $0.62(0.25)$ a B \\
\hline \multicolumn{4}{|l|}{ Leaf dry matter (\%) } \\
\hline & Wet & $52.43(0.54) \mathrm{a}$ & $48.60(2.19) \mathrm{a}$ \\
\hline & Moderate & $48.16(6.75) \mathrm{a}$ & $34.40(1.28) \mathrm{b}$ \\
\hline & Dry & $46.23(2.11) \mathrm{a}$ & 34.85 (4.67) b \\
\hline \multicolumn{4}{|l|}{ Stem dry matter (\%) } \\
\hline & Wet & $21.97(1.23) \mathrm{a}$ & $26.10(2.20) \mathrm{a}$ \\
\hline & Moderate & $22.94(2.26) \mathrm{a}$ & $32.22(1.33) \mathrm{a}$ \\
\hline & Dry & $22.52(1.70) \mathrm{a}$ & $26.50(1.52) \mathrm{a}$ \\
\hline \multicolumn{4}{|l|}{ Root dry matter (\%) } \\
\hline & Wet & $25.60(1.44) \mathrm{a}$ & $25.32(2.97)$ a \\
\hline & Moderate & $28.90(4.60) \mathrm{a}$ & $33.40(1.27) \mathrm{ab}$ \\
\hline & Dry & $31.25(2.77) \mathrm{a}$ & $38.19(2.96) \mathrm{b}$ \\
\hline
\end{tabular}

Table 2. Effect of watering treatment on root mass: leaf area ratio of $K$. anthotheca and $K$. ivorensis seedlings. Each value is the mean of three plants $( \pm \mathrm{SE})$. Within each species, means in a column followed by same letters are not significantly different (Fisher LSD test, $P<0.05$ ).

\begin{tabular}{|c|c|c|c|c|}
\hline \multirow[b]{2}{*}{ Parameter } & \multirow[b]{2}{*}{ Watering regime } & \multirow[b]{2}{*}{ K. anthotheca } & \multirow[b]{2}{*}{ K. ivorensis } & \multirow{2}{*}{$\begin{array}{c}\text { Between species } \\
\text { Proportional change }\end{array}$} \\
\hline & & & & \\
\hline \multirow[t]{3}{*}{$\begin{array}{l}\text { root mass: Leaf area } \\
\qquad\left(\mathrm{x} 10^{-3} \mathrm{~g} \mathrm{~cm}^{-2}\right)\end{array}$} & Wet & $2.3(0.0003) \mathrm{a}$ & $2.4(0.0002) \mathrm{a}$ & $7 \%$ \\
\hline & Moderate & $3.0(0.0006) \mathrm{a}$ & $4.0(0.0001) \mathrm{ab}$ & $33 \%$ \\
\hline & Dry & $4.0(0.0004) \mathrm{a}$ & $6.0(0.001) b$ & $50 \%$ \\
\hline
\end{tabular}

\section{DISCUSSION}

Several investigators have reported for many woody species that biomass accumulation, growth and physiological processes of carbon fixation were highly sensitive to stress conditions caused by shortage of water in soil (Bahari et al., 1985; Osório et al., 1998; Ngugi et al., 2003). Within a local area, the strength of genetic control of height growth of trees within a species tends to be low and site factors such as soil water and nutrients are major determinants of height growth (Burton et al., 1998). In this study, Khaya ivorensis attained highest height growth and largest biomass production under wet treatment indicating that water deficit impacted negatively on height growth and biomass production (Fig. 1 and Table 1). Watering treatments only influenced significantly height growth of $K$. anthotheca. The decrease in height growth of $K$. anthotheca in the wet treatment may be attributed to excess standing water maintained at the base of the pots which caused poor aeration. This might have led to an inhibition of oxygen supply to roots and concomitantly reduction of water and mineral conductivity (Kramer \& Jackson, 1954). The absence of marked treatment effects on dry mass production and allocation in $K$. anthotheca in this study may have resulted from the small sample size and from shorter duration of the experiment as 
reported for other plants (Ledig, 1983). Hawthorne (1994) suggested that $K$. ivorensis is suitable for plantation in low-lying areas with moist site conditions (1500-1750 mm of annual precipitation). Inference from Hall \& Swaine (1981) indicate that $K$. anthotheca thrive best at sites intermediate in moisture where forest ochrosols (less leached soil, better supplied with nutrient and slightly acidic to neutral) dominates. As expected, K. ivorensis grew best in the wet treatment whereas $K$. anthotheca grew best in the moderate treatment.

Water stress has been recognized to alter the allocation of dry matter to leaves and supporting biomass. An increase in mass of roots and a decrease in carbon allocation to leaves are considered typical acclimation mechanism in response to water shortage (Pereira \& Chaves, 1993). In this study, K. ivorensis from wetter site showed large increase in root mass: foliage area ratio than $K$. anthotheca under water stress (Table 2). A species showing this acclimation is less drought-tolerant because it may not have any physical mechanism to avoid drought stress. In contrast, $K$. anthotheca which is typically found in the NW subtype (drier site), showed similar root mass: foliage area ratio in the moderate and dry treatments suggesting that $K$. anthotheca is more tolerant to drought. In a field guide to forest trees of Ghana, Hawthorne (1990) describes the leaflets of $K$. anthotheca as being dry on the lower surface with leathery appearance and with or without impressed larger veins enhancing the ability of $K$. anthotheca to tolerate desiccation of leaf tissue better than K. ivorensis.

These characteristic traits have partly shown that seedlings of $K$. anthotheca have considerable potential for use in plantation forestry in the humid tropics of Africa which has a wide rainfall distribution range and distinct drought periods ( $4-5$ months). This is shown by the species remarkable height growth under moderate water stress condition. Seedlings of $K$. ivorensis on the other hand are more suited for planting on moist site (lowlying areas with $1500-1750 \mathrm{~mm}$ of annual precipitation) as demonstrated by the species ability to grow best in wet condition. The result of this study may have implications in matching the two Khaya species to sites different in water availability but we recommend further research in other aspects, such as growth of larger juveniles and adults under field conditions, mortality by water stress as well as information on leaf gas exchange.

ACKNOWLEDGEMENTS The first author is grateful to the Ministry of Education, Science and Culture of Japan for providing financial support while studying at The United Graduate School of Agricultural Sciences, Kagoshima University.

\section{REFERENCES}

Bahari, Z. A., Pallardy, S. G \& Parker, W. C. 1985. Photosynthesis, water relations and drought adaptation in six woody species of oak-hickory forest in Central Missouri. Forest Science 31: 557-569.

Burton, V. B., Zak, R. D., Denton, R. S. \& Spurr, S. H. 1998. Forest ecology 4th edn. John Wiley and sons, Inc., New York, USA. 774p.

Haase, D. L \& Rose, R. 1993. Effect of soil water content and initial root volume on the nutrient status of $2+0$ Douglas-fir seedlings. New Forests 7: 1-17.

Hall, J. B \& Swaine, M. D. 1976. Classification and ecology of closed-canopy forest in Ghana. Journal of Ecology 64: 913-951.

Hall, J. B \& Swaine, M. D. 1981. Distribution and vascular plants in a tropical rain forest (forest vegetation in Ghana). Geobotanyl. W. Junk, The Hague. 383p.

Hawthorne, W. D. 1990. Field guide to the forest trees of Ghana. Natural Resources Institute, ODA, London. $278 \mathrm{p}$.

Hawthorne, W. D. 1994. Fire damage and forest regeneration in Ghana. ODA Forestry series No.4. $53 \mathrm{p}$.

Hawthorne, W. D. 1995. Ecological profiles of Ghanaian forest trees. Oxford Forestry Institute, Oxford. $345 \mathrm{p}$.

Hawthorne, W. D. 2001. Forest conservation in Ghana. Pp. 491-512. In: African Rainforest Ecology and Conservation. (Weber, W., White, J. T. L., Verdder, A. \& Treves, L. N. eds.) Yale University Press, New Haven. 588p.

Ito, S., Nishiyma, Y. \& Kustiawan, W. 2000. Responses of dipterocarp seedlings to drought stress. Pp. 144151. In: Rainforest Ecosystems of East Kalimantan: El Niño, Drought, Fire and Human Impacts. Ecological studies Vol. 140. (Gurhardja, E., Fatawi, M., Sutisna, M., Mori, T. \& Ohta, S. eds.) Springer-Verlag, Tokyo.

Kozlowski, T. T. 1979. Tree growth and environmental stresses. University of Washington Press, Seattle, $192 \mathrm{p}$.

Kramer, P. J. \& Jackson, W. T. 1954. Causes of injury to flooded tobacco plants. Plant Physiology 29: 241-245.

Ledig, F. T. 1983. The influence of genotype and 
environment on dry matter distribution in plants. Pp. 427-454 In: Plant research and agroforestry (Huxley, P. A ed.) Proceedings of consultative meeting, International Council Resources Agroforestry. Nairobi, Kenya.

Li, C., Berninger, F., Koskela, J. \& Sonnien, E. 2000. Drought responses in Eucalyptus microtheca provenances depend on seasonality of rainfall in their place of origin. Australian Journal of Plant Physiology 27: 231-238.

Nagatomo, Y. \& Tamai, M. 1993. Chemical properties of Akahoya soils. Bulletin of the Faculty of Agriculture, Miyazaki University 40: 31-40

Ngugi, R. M., Hunt A. M., Doley, D., Ryan, P. \& Dart, P. 2003. Dry matter production and allocation in Eucalyptus cloeziana and Eucalyptus argophloia seedlings in response to soil water deficits. New Forests 26: 187-200.

Osório, J., Osório, M. L., Chaves, M. M. \& Pereira, J. S. 1998. Water deficits are more important in delaying growth than changing patterns of carbon allocation in Eucalyptus globulus. Tree Physiology 18: 363-373.

Pereira, J. S. \& Chaves, M. M. 1993. Plant water deficits in Mediterranean ecosystems. Pp. 235-251. In: Water deficits: Plant response from cell to community. (Smith, J. A. C. and Griffiths, H. eds.) Bios Scientific Publishers, Oxford.

Sokal, R. R \& Rohlf, F. J. 1995. Biometry: The principles and practice of statistics in biological research. Freeman and Company, New York. 887pp.

Received $8^{\text {th }}$ July 2005

Accepted $22^{\text {nd }}$ Nov. 2005 